\title{
Experimental and Numerical Investigation of the Steel X210Cr12 Forming in Semi-solid State
}

\author{
Mária Behúlová ${ }^{1, a}$, David Aišman ${ }^{2, b}$, Hana Jirková2,c, Bohuslav Mašek ${ }^{2, d}$ \\ ${ }^{1}$ Slovak University of Technology in Bratislava, Faculty of Materials Science and Technology \\ in Trnava, Paulínska 16, 91724 Trnava, Slovak Republic \\ ${ }^{2}$ University of West Bohemia in Pilsen, Research Centre of Forming Technology, Univerzitní 22, \\ 30614 Pilsen, Czech Republic

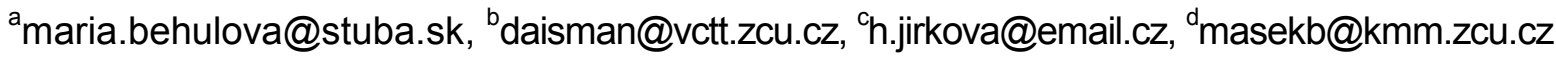

\begin{abstract}
Keywords: semi-solid state, $\mathrm{X} 210 \mathrm{Cr} 12$ steel, microstructural analysis, phase composition,
\end{abstract} numerical simulation, die cavity filling

\begin{abstract}
Semi-solid forming processes belong to the progressive technologies which can be exploited for the manufacturing products with complicated shapes and special material and utility properties. Semi-solid metal forming takes place at temperatures between solidus and liquidus combining the advantages of metal forging and metal casting processes. The paper is focused on the analysis of microstructures and phase composition of the X210Cr12 steel identified in the thin-walled products after forming in semi-solid state. Microstructure of the X210Cr12 steel after rapid cooling and solidification from semi-solid state is formed by quasi-globular grains of metastable austenite surrounded by carbides and fine eutectics. The fraction of metastable austenite in structure was found to be $96 \%$ exhibiting the thermal stability up to the temperature of $500{ }^{\circ} \mathrm{C}$. Along with experimental study, the numerical analysis of the material flow during a die cavity filling was carried out using developed 2D simulation model taking into account one-phase non-newtonian flow.
\end{abstract}

\section{Introduction}

During the past decades, material forming in semi-solid state has been applied for a wide range of alloys. In the initial stage of investigation of semi-solid forming processes, the attention was focused mainly on the low-melted alloys [1-3]. Later, the interest was concentrated also on the high-strength low-alloyed steels, tool steels and cast iron [4-7]. For the processes of metal forming in semi-solid state, the recommended fraction of molten phase is from $40 \%$ to $60 \%$ [4, 8]. Moreover, the material in semi-solid state suitable for forming should be formed by the mixture of molten metal and solid particles with globular shape. After the semiproduct heating to the temperature between solidus and liquidus, material is formed in closed or open die cavity. Due to the rapid heat extraction from slurry material to the die, the solidification occurs under non-equilibrium conditions resulting in the fine microstructure development and attaining specific material properties which are unreachable using technologies applying conventional cooling rates [9].

In the paper, the microstructure and phase composition of the $\mathrm{X} 210 \mathrm{Cr} 12$ steel developed in the miniature thin-walled product prepared by newly designed technology of thixoforming are evaluated. Numerical simulation of material flow in semi-solid state based on 2D simulation model is applied to investigate the complex problem of a die cavity filling during thixoforming.

\section{Experimental material and equipment}

For the experimental investigation of a new technology of thixoforming, the steel $\mathrm{X} 210 \mathrm{Cr} 12$ of ledeburite type with the chemical composition given in the Table 1 was chosen. This tool steel is typical by the high wear resistance and high strength but also by difficult formability and machinability applying conventional technologies. It is exploited particularly as a material for tools dedicated for cold forming. From the point of view of the material forming in semi-solid state, a wide 
Table 1: Chemical composition of the X210Cr12 steel [wt. \%]

\begin{tabular}{|c|c|c|c|c|c|c|}
\hline $\mathrm{C}$ & $\mathrm{Cr}$ & $\mathrm{Mn}$ & $\mathrm{Si}$ & $\mathrm{Ni}$ & $\mathrm{P}$ & $\mathrm{S}$ \\
\hline $1.8-2.05$ & $11.0-12.5$ & $0.2-0.45$ & $0.2-0.45$ & $\max 0.5$ & $\max 0.03$ & $\max 0.035$ \\
\hline
\end{tabular}

temperature range between solidus and liquidus represents a very important property of the X $210 \mathrm{Cr} 12$ alloy as the maintenance of the accurate temperature and liquid fraction during the heating process is quite difficult task. Using the program code JMatPro, the solidus and liquidus temperatures of the steel X210Cr12 were calculated to be $T_{\mathrm{S}}=1240^{\circ} \mathrm{C}$ and $T_{\mathrm{L}}=1375^{\circ} \mathrm{C}$, respectively. The temperature interval from $1290{ }^{\circ} \mathrm{C}$ to $1330{ }^{\circ} \mathrm{C}$ corresponds to the fraction of liquid phase from $40 \%$ to $60 \%$ recommended for the material forming in semi-solid state.

The new technology of thixoforming is experimentally tested using the equipment which principle is illustrated in Fig. 1a. The semiproduct of cylindrical shape with the ending in the form of frustum of a cone is put into a die consisting of four parts. This enables easy manipulation with the semiproduct and a simple die disassembly. The semiproduct is heated quite fast to the semi-solid state directly inside the die using developed high frequency resistance heating [10]. Temperatures are measured and controlled with a very high accuracy therefore the compression force can be applied exactly at the defined temperature. After the filling a die cavity, the semi-solid material rapidly solidifies due to the heat extraction to the die.

The semi-product with the diameter of $6 \mathrm{~mm}$ and different lengths were tested. According to results of numerical simulation [11], the volume of material with the temperature above the solidus temperature at the end of heating is greater for larger semiproducts (Fig. 1b). At the same time, the volume of material heated to the temperatures suitable for thixoforming increases (Table 2).

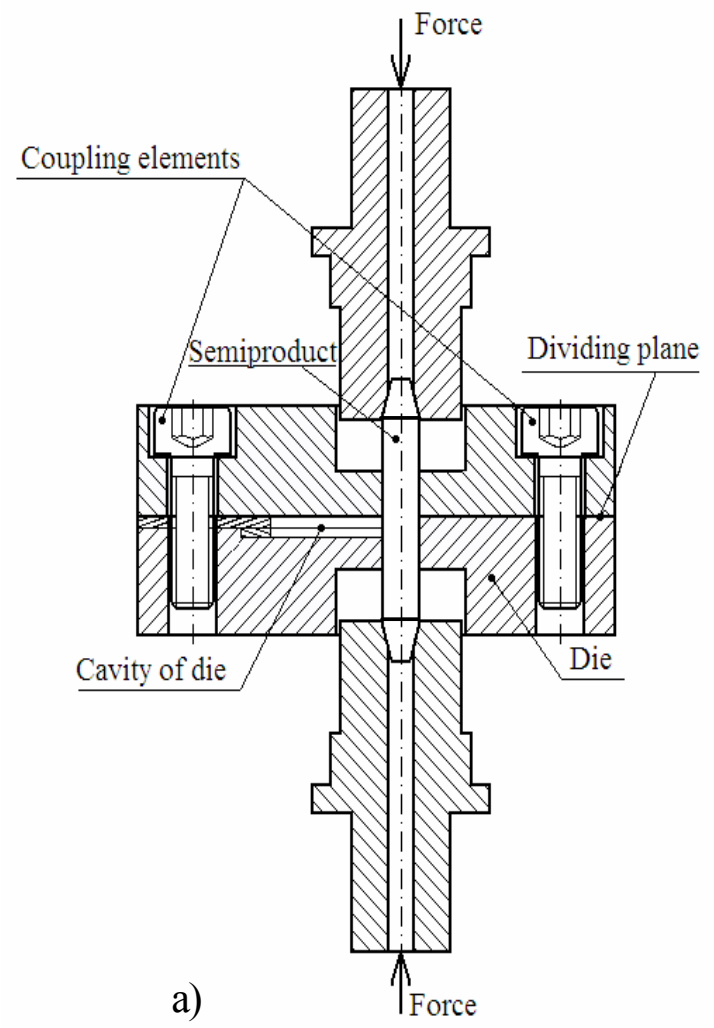

a)

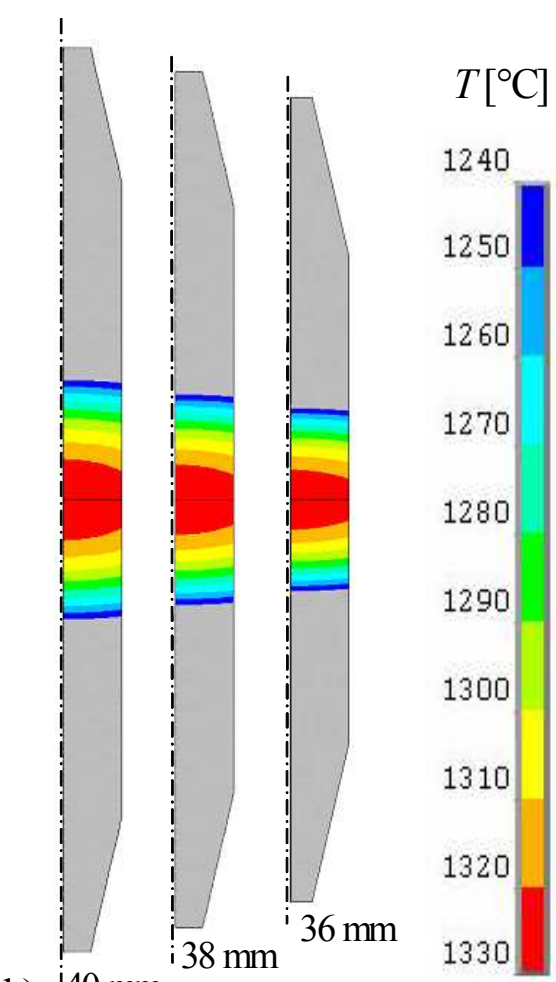

b) $40 \mathrm{~mm}$

Fig. 1: Principle of the technology of thixoforming (a) and mushy zones with the temperatures from $1240{ }^{\circ} \mathrm{C}$ to $1330{ }^{\circ} \mathrm{C}$ in the semiproduct of different lengths (b) 
Table 2: Dependence of the volume of semi-solid material on the semiproduct length

\begin{tabular}{|c|c|c|c|}
\hline \multirow{2}{*}{$\begin{array}{c}\text { Volume of material }\left[\mathrm{mm}^{\mathbf{3}} \text { ] with the }\right. \\
\text { temperature }\end{array}$} & \multicolumn{3}{|c|}{ Length of a semiproduct } \\
\cline { 2 - 4 } & $\mathbf{4 0} \mathbf{~ m m}$ & $\mathbf{3 8} \mathbf{~ m m}$ & $\mathbf{3 6} \mathbf{~ m m}$ \\
\hline above solidus temperature & 149.7 & 127.2 & 113.1 \\
\hline in the interval from $1290^{\circ} \mathrm{C}$ to $1330^{\circ} \mathrm{C}$ & 91.5 & 80.3 & 70.7 \\
\hline
\end{tabular}

\section{Microstructural analysis and numerical simulation}

To study the principal phenomena and processes occurring during the forming of the $\mathrm{X} 210 \mathrm{Cr} 12$ steel in semi-solid state, the die cavity with the shape of elongated groove with rectangular cross-section was chosen (Fig. 2a) [12,13]. The material for experiments was in as-formed annealed state. The initial structure was formed by a ferrite matrix with chromium carbides (Fig. 2b). Metallographic analysis revealed that the structure after thixoforming consisted of quasi- globular grains of metastable austenite surrounded by carbides and fine eutectics (Fig. 2c). Using the X-ray diffraction phase analyses, the fraction of metastable austenite in structure was found to be $96 \%$ $[13,14]$. The development of microstructure with such high fraction of austenite resulted not only from the contribution of chemical composition but also from rapid material cooling, rapid non-equilibrium solidification and structure development under high applied pressure.

For evaluation of stability of metastable austenite, experimental samples were subjected to the thermal loading. The metastable austenite remains stable up to the temperature of $500^{\circ} \mathrm{C}$ when the first visible changes of microstructure were identified (Fig. 2d). During the cooling to the room temperature after the thermal exposition at $550^{\circ} \mathrm{C}$, the transformation of metastable austenite to the martensite occurred leading to the hardness enhancement (Table 3). According the X-ray diffraction phase analysis, the fraction of metastable austenite in structure after one hour exposition at the temperature of $550^{\circ} \mathrm{C}$ was only $5 \%$. The increase of exposition temperature to $600{ }^{\circ} \mathrm{C}$ resulted in intensive diffusion process and austenite decomposition. The results corresponds to the high thermal stability of metastable austenite in rapidly solidified powder particles from a $\mathrm{Cr}-\mathrm{Mo}-\mathrm{V}$ tool steel of ledeburite type prepared by nitrogen gas atomization [15].

Table 3: Influence of material treatment on the fraction of metastable austenite and hardness

\begin{tabular}{|c|c|c|c|c|c|c|c|}
\hline Material treatment & $\begin{array}{c}\text { Steel in } \\
\text { annealed state }\end{array}$ & $\begin{array}{c}\text { After } \\
\text { thixoforming }\end{array}$ & $\mathbf{2 0 0}^{\circ} \mathbf{C} / \mathbf{1 h}$ & $\mathbf{3 5 0}{ }^{\circ} \mathbf{C} / \mathbf{1} \mathbf{h}$ & $\mathbf{5 0 0}^{\circ} \mathbf{C} / \mathbf{1} \mathbf{h} 550^{\circ} \mathbf{C} / \mathbf{1} \mathbf{h}$ & $\mathbf{6 0 0}^{\circ} \mathbf{C} / \mathbf{1 h}$ \\
\hline $\begin{array}{c}\text { Percentage } \\
\text { of metastable austenite }\end{array}$ & - & $96 \%$ & $95 \%$ & $96 \%$ & $89 \%$ & $5 \%$ & $1 \%$ \\
\hline Hardness HV 10 & 203 & 332 & 375 & 461 & 443 & 757 & 597 \\
\hline
\end{tabular}



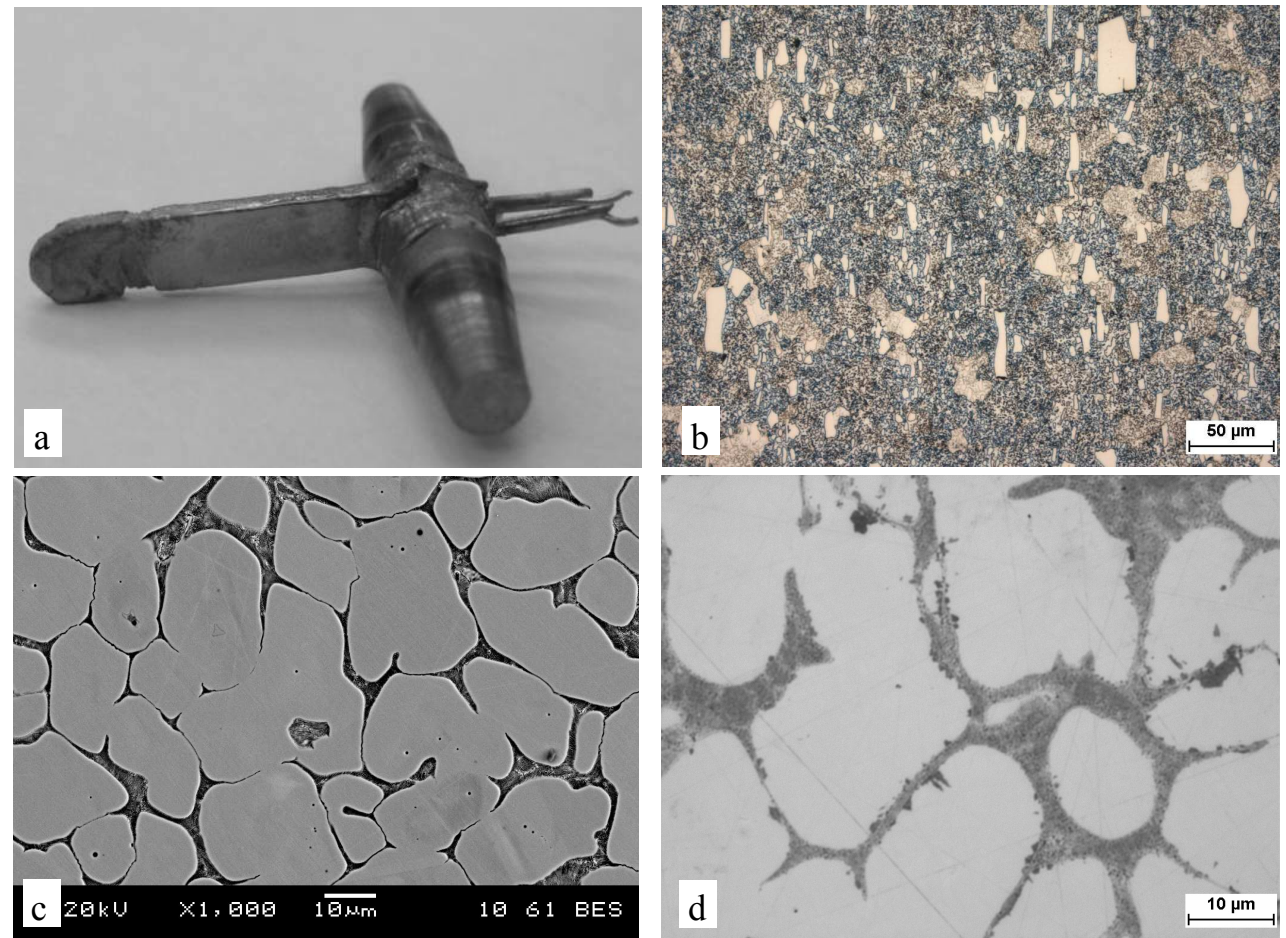

Fig. 2: Demonstrator obtained by thixoforming (a) and microstructure of the $\mathrm{X} 210 \mathrm{Cr} 12$ steel in the initial state (b), after thixoforming (c) and after tempering at $500{ }^{\circ} \mathrm{C}$ for 1 hour

The numerical analysis of the process of a die cavity filling during thixoforming was performed by the program code ANSYS10.0/FLOTRAN as a coupled transient fluid and thermal problem supposing the turbulent flow of incompressible fluid [16]. In Fig. 3a the simplified 2D geometrical model the semi-product is shown. The finite element mesh consisted of more than 40000 elements in order to assure the solution convergence. Material properties of the X210 Cr12 steel in the dependence on temperature were computed using the program code JMatPro. The Ostwald-de-Waele model was applied to model the material behavior in thixotropic state $[8,16]$.

According to the results of numerical simulation, the duration of a die cavity filling is shorter than $0.01 \mathrm{sec}$ (Fig. 3c). The maximal computed flow velocities reach the values of $4 \mathrm{~m} . \mathrm{s}^{-1}$. However, due to the high compression loading, geometry of the cavity, shape of the cavity inlet and viscosity of material in semi-solid state, the slurry material is injected to the central parts of a die cavity and it completes the area near the cavity surface by the backwards motion of the melt. This result can be supported by the structure of the final product (Fig. 3b) indicating the possible existence of return flow by the visible interface between microstructure in the central and boundary parts of the obtained product. From this point of view, the modification of the die inlet can be recommended. 

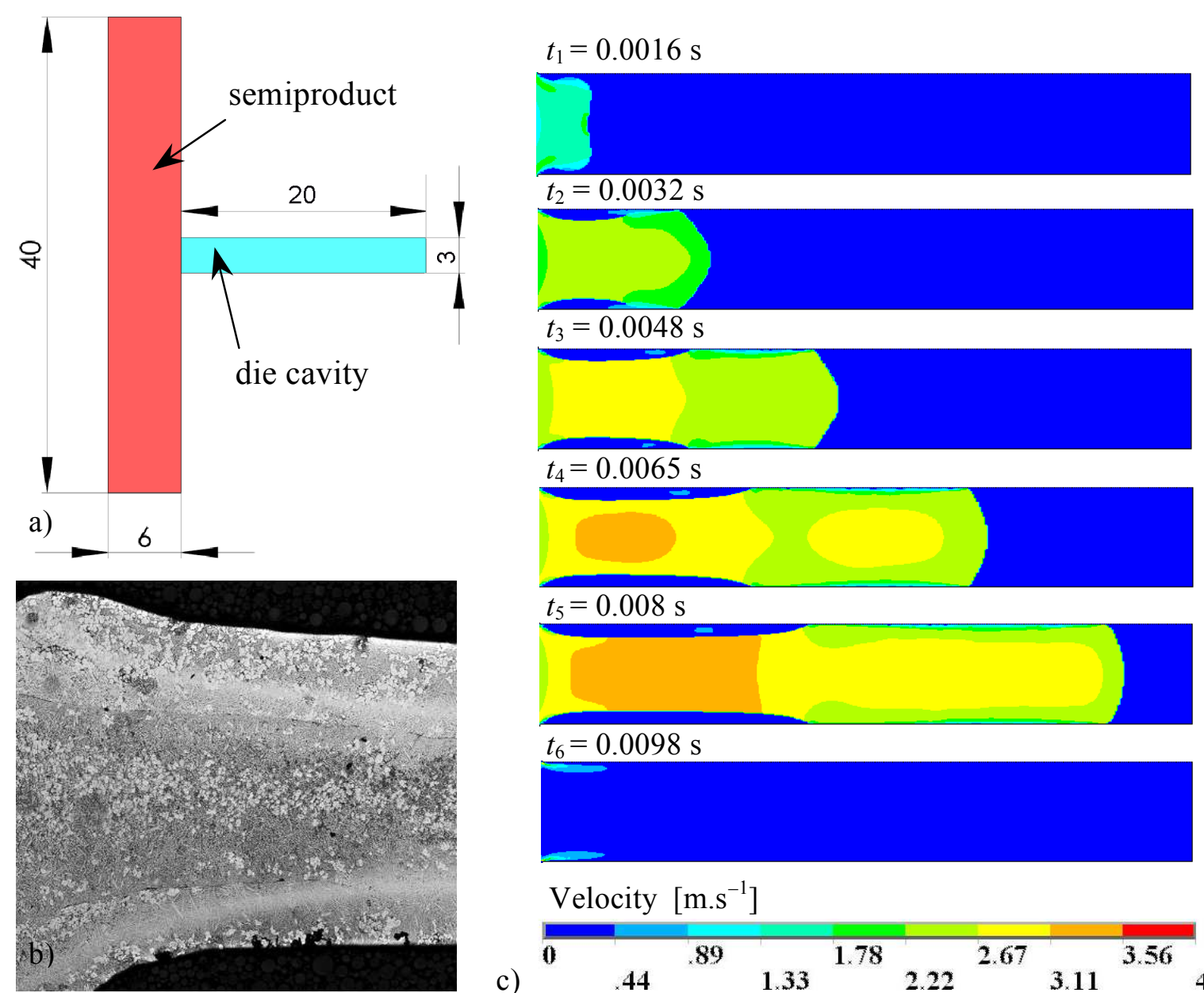

$t_{6}=0.0098 \mathrm{~s}$

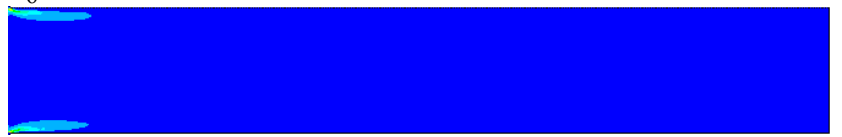

Velocity $\left[\mathrm{m} \cdot \mathrm{s}^{-1}\right]$

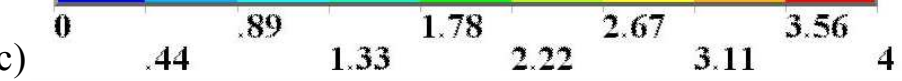

Fig. 3: Geometrical model for numerical simulation (a), detail from the microstructure of obtained product (b) and computed velocity fields in chosen times during filling the die cavity (c)

\section{Conclusions}

Particular results obtained in connection with the investigation of a newly designed process of thixoforming of the $\mathrm{X} 210 \mathrm{Cr} 12$ steel are presented in the paper. This technology exploits advantages of rapid high-frequency heating of a semiproduct directly inside the die followed by fast filling of a die cavity with material in semi-solid state due to the applied compression loading. Microstructure of the $\mathrm{X} 210 \mathrm{Cr} 12$ steel after rapid solidification under pressure is formed by quasi-globular grains of metastable austenite surrounded by carbides and fine eutectic network. The fraction of metastable austenite in structure was found to be $96 \%$. The structure remains stable during thermal exposition up to the temperature of $500{ }^{\circ} \mathrm{C}$.

The numerical simulation revealed that the process of the die cavity filling by the material in semi-solid state was finished by the time shorter than 0.01 second. The maximal computed flow velocities were up to $4 \mathrm{~m} \cdot \mathrm{s}^{-1}$. Under the supposed conditions of compression loading, the volume of a die cavity is not filled continuously. The presence of return flow can result in the different microstructure development in the central and peripheral parts of a final product. To improve the material flow, the modification of the die inlet is recommended.

\section{Acknowledgements}

The research was supported by the VEGA MŠ SR and SAV within the project 1/0837/08, project 1M06032 Research Centre of Forming Technology and the Slovak and Czech Bilateral Project SK-CZ-0180-09. 


\section{References}

[1] M. C. Flemings: Metallurgical Science and Technology Vol. 18 No. 2 (2000) p. 1

[2] M. Kiuchi, R. Kopp: CIRP Annals - Manufacturing Technology Vol. 51 Issue 2 (2002) p. 653

[3] B. Hallstedt, E. Balithev, H. Shimahara, D. Neuschutz: ISIJ International, Vol. 46 No. 12 (2006) p. 1852

[4] G. Hirt, R. Kopp: Thixoforming. (WILEY-VCH Verlag GmbH \& Co. KGaA, Weinheim 2009)

[5] W. Püttgen, W. Bleck, G. Hirt, H. Shimara: Advanced Enginnering Materials, 9, No. 4 (2007), p. 231

[6] W. Püttgen, B. Hallstedt, W. Bleck, P. J. Uggowitzer: Acta Materialia Vol. 55 Issue 3 (2007), p. 1033

[7] G. Hirt, G. et al.: CIRP Annals - Manufacturing Technology Vol. 54 Issue 1 (2005) p. 257

[8] H. V. Atkinson: Modelling of semi-solid processing (Aachen, Shaker 2008)

[9] Staňková, H. et al.: Influence of Thixoforming on Structure Development of the Tool Steel. In.: 12th International Research/Expert Conference - TMT 2008, Turkey

[10] Ronešová, B. Mašek: U.S. Patent 7,480,155 (2009)

[11] M. Behúlová: Aerospace Sciences \& Aviation Technology Vol. 1 (2009) p. 1

[12] D. Aišman, H. Jirková, B. Mašek, in: Proceedings of the 20th International DAAAM Symposium Vol. 20 No. 1 (2009) p. 1895

[13] H. Jirková, D. Aišman, B. Mašek: Journal of Alloys and Compounds Vol. 504 (2010) p. S500.

[14] B. Mašek, D. Aišman, M. Behúlová, H. Jirková: Transactions of Nonferrous Metals Society of China. Vol. 20 (2010), p. 1037

[15] P. Grgač, R. Moravčík, M. Kusý, I. Tóth, M. Miglierini, E. Illeková: Materials Science and Engineering A Vol. 375-377 (2004), p. 581

[16] ANSYS Theoretical Manual, Release 10.0, SAS IP, Inc., 2005 